\title{
Assessment of Hypervolemia by Cyclic 3'5'-Guanosine Monophosphate in Pediatric Patients on Hemodialysis
}

\author{
Thomas Sitter $^{a}$ Verena Holzgartner ${ }^{a} \quad$ Gernot Wolfram $^{b}$ Marcel Toepfer ${ }^{a}$ Bernd Klare ${ }^{c}$ \\ Rupert Gerzer ${ }^{b}$ Helmut Schiffla \\ aDepartment of Nephrology, Medizinische Klinik, Klinikum Innenstadt, Ludwig-Maximilians-Universität München, \\ ${ }^{b}$ Deutsches Zentrum für Luft- und Raumfahrtmedizin, Köln, und 'Pediatric Dialysis Unit, \\ Technische Universität München, Deutschland
}

Dear Sir,

The exact determination of the hydration state represents one of the central problems of maintenance hemodialysis therapy [1]. Usually, clinical signs, radiological features on chest X-ray and echocardiography are used for the determination of dry body weight. However, these criteria are relatively insensitive and, as a consequence, a considerable number of hemodialysis patients remain overhydrated. In children with endstage renal disease assessment of dry body weight is particularly difficult. Weight gain may be interpreted as growth although it might be caused by sodium and water retention.

Extracellular fluid volume overload is the major stimulus for secretion of atrial natriuretic peptide (ANP) and its second messenger cyclic 3'5'-guanosine monophosphate (cGMP). In a number of studies we have shown that plasma cGMP levels are reliable markers for fluid overload in adults on renal replacement therapy with normal heart function [2-4]. In order to test the ability of cGMP as a possible biochemical marker for fluid overload in children, we designed a prospective longitudinal study. Pre- and postdialytic cGMP concentrations were measured over a period of 9 months ( 9 repeated measurements for each patient) in 15 children and adolescents $(9$ males, 6 females) with end-stage renal disease treated by intermittent hemodialysis $(4 \mathrm{~h}$ three times per week). The age ranged between 8 and 19 years with a mean age of $15 \pm 3$ years. The primary kidney diseases were dysplastic kidneys (5 patients), glomerulonephritis ( 3 patients), nephronophtisis (2 patients), amyloidosis (2 patients), Alport's syndrome (1 patient), hyperoxaluria (1 patient) and polycystic kidney disease (1 patient). The ideal body dry weight was estimated in all patients at the beginning of the study by clinical means, echocardiography, vena cava diameter and chest X-ray. Fifteen healthy sex- and age-matched children and adolescents served as controls. cGMP was determined in alcohol-extracted plasma by radioimmunoassay as has been described in detail previously [5].

Compared with healthy controls, the predialytic plasma concentrations of cGMP were markedly elevated in all 15 volumeexpanded hemodialyzed children (16.8 \pm 7.1 vs. $4.2 \pm 1.8 \mathrm{pmol} / \mathrm{ml} ; \mathrm{p}<0.05$ ). Before hemodialysis, the mean body weight exceeded the estimated dry weight by $1.8 \pm$ $0.6 \mathrm{~kg}$. The circulating cGMP values in these patients were influenced by their residual renal function: children with daily urinary excretion over $200 \mathrm{ml}$ had significantly lower predialytic plasma cGMP levels than did those with anuria $(13.3 \pm 5.6$ vs. $23.4 \pm$ $4.3 \mathrm{pmol} / \mathrm{ml} ; \mathrm{p}<0.05)$. In contrast, postdialytic cGMP values were not influenced by urinary volume $(6.6 \pm 2.3$ vs. $6.2 \pm$ $2.7 \mathrm{pmol} / \mathrm{ml})$.

Removal of excess body fluid during hemodialysis resulted in a significant decrease in cGMP values $(6.7 \pm 2.2$ vs. $16.8 \pm$ $7.1 \mathrm{pmol} / \mathrm{ml} ; \mathrm{p}<0.05$ ) (fig. $1 \mathrm{~A})$. However, postdialytic cGMP levels were still significantly higher than in normal controls $(6.7 \pm$ 2.2 vs. $4.2 \pm 1.8 \mathrm{pmol} / \mathrm{ml} ; \mathrm{p}<0.05)$. None of our studied patients had on an average a postdialytic cGMP concentration over $10 \mathrm{pmol} / \mathrm{ml}$ during the 9-month follow-up. As shown in figure $1 \mathrm{~B}$, the reduction in body

\section{KARGER \\ Fax +4161306 1234 \\ E-Mail karger@karger.ch} www. karger.com (c) 1999 S. Karger AG, Basel

0028-2766/99/0833-0287\$17.50/0

Accessible online at:

http://BioMedNet.com/karger
Dr. Thomas Sitte

Medizinische Klinik, Klinikum Innenstadt der Universität München

Ziemssenstrasse 1

D-80336 München (Germany), Tel +49 8951602129

Fax +49 895160 4924, E-Mail Thomas.Sitter@medinn.med.uni-muenchen.de 
weight during hemodialysis correlates significantly with the decrease in cGMP during our follow up of 9 months $(\mathrm{r}=0.67, \mathrm{p}<$ 0.01 ).

Confirming previous reports of elevated ANP and/or cGMP levels in adults [2-4, 6] or children $[7,8]$ on hemodialysis, our study extends the observation to children by monitoring pre- and postdialytic plasma cGMP levels over a long period. During a 9-month follow-up, dry weight of studied children was assessed by clinical signs and/or noninvasive technical parameters. Over this time period we found a significant correlation between percent reduction in body weight and changes in plasma cGMP levels. According to the results of previous studies in adults [2, 3] removal of excess body fluid by dialysis was associated with a significant decrease, but not with normalization of cGMP in children. Since the mean postdialytic cGMP concentration was below $10 \mathrm{pmol} / \mathrm{ml}$ for each of our patient, we consider this value as the upper limit of 'normal range' in children. None of these patients exhibiting such a postdialytic value had echocardiographic signs of fluid overload. In addition, postdialytic cGMP has been shown to be correlated with other parameters defining dry body weight of hemodialysis patients, such as inferior caval vein diameter [9], computed tomographic measurements of lung density [9] and bioimpedance (conductivity measurements) [6].

Although clinical evaluation remains the first step in the assessment of dry body weight, it is sometimes difficult to exclude minor hypervolemia in children. We conclude from our data that postdialytic plasma cGMP is a sensitive and easily accessible biochemical marker for hypervolemia in pediatric patients on hemodialysis. Determination of cGMP in addition to the clinical assessment of hydration state may reduce the necessity for chest X-ray or invasive procedures in these patients.

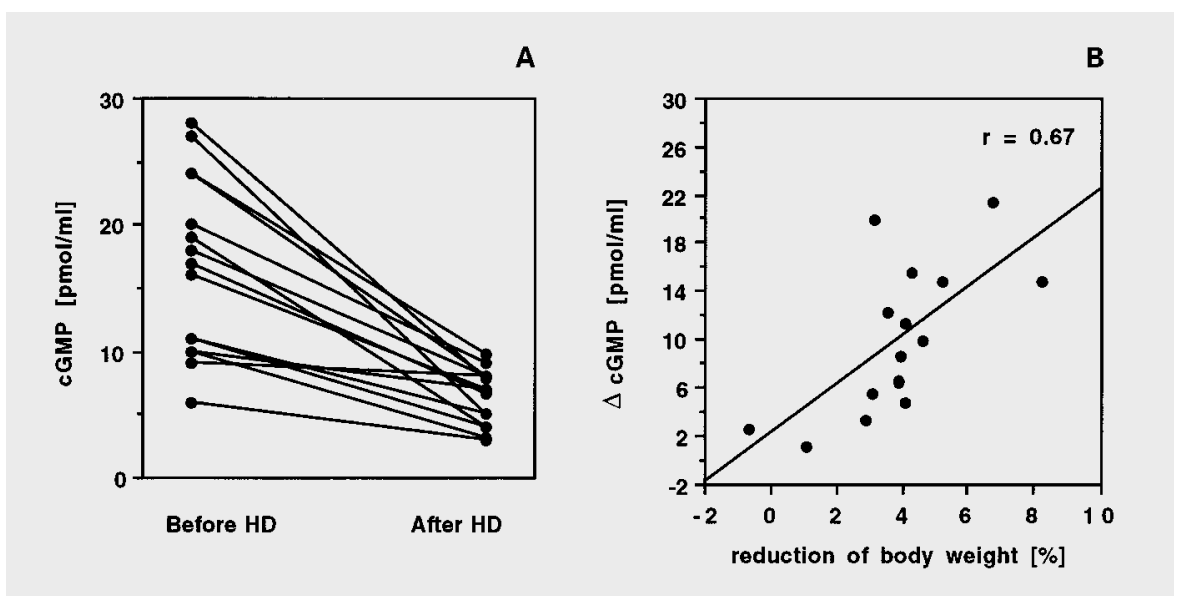

Fig. 1. A Plasma cGMP levels in 15 children before and after HD. Each point represents the mean of 9 measurements during 9 months. B Correlation between changes in cGMP $(\Delta c G M P)$ and percent reduction in body weight during hemodialysis treatment $(n=15)$. Each point represents the mean of 9 measurements during 9 months.

\section{References}

1 Leypoldt JK, Cheung AK: Evaluating volume status in hemodialysis patients. Adv Ren Replace Ther 1998;5:64-74.

2 Lauster F, Gerzer R, Weil J, Fülle HJ, Schiffl $\mathrm{H}$ : Assessment of dry body-weight in haemodialysis patients by the biochemical marker cGMP. Nephrol Dial Transplant 1990;5:356361.

3 Lauster F, Fülle HJ, Gerzer R, Schiffl H: The postdialytic plasma cyclic guanosine $3^{\prime}: 5^{\prime}$ monophosphate level as a measure of fluid overload in chronic hemodialysis. J Am Soc Nephrol 1992;2:1451-1454.

4 Lauster F, Heim JM, Drummer C, Fülle HJ, Gerzer R, Schiffl H: Plasma cGMP level as a marker of the hydration state in renal replacement therapy. Kidney Int 1993;(suppl 41):5759.

5 Heim JM, Gottmann K, Weil J, Haufe MC, Gerzer R: Is cyclic GMP a clinically useful marker for ANF action? Z Kardiol 1988;2:4146.
6 Kouw PM, Kooman JP, Cheriex EC, Olthof CG, de Vries PM, Leunissen KM: Assessment of postdialysis dry weight: A comparison of techniques. J Am Soc Nephrol 1993;4:98-104.

7 Rascher W, Tulassay T, Lang RE: Atrial natriuretic peptide in plasma of volume-overloaded children with chronic renal failure. Lancet 1985;ii:303-305.

8 Lettgen B, Bald M, Vallee H, Bonzel KE, Rascher W: Atrial natriuretic peptide and cyclic 3'5'-guanosine monophosphate as indicators of fluid volume overload in children with chronic renal failure. Pediatr Nephrol 1992;6: 60-64.

9 Metry G, Wegenius G, Wikstrom B, Kallskog V, Hansell P, Lindgren PG, Hedenstrom H, Danielson BG: Lung density for assessment of hydration status in hemodialysis patients using the computed tomographic densitometry technique. Kidney Int 1997;52:1635-1644. 